\title{
RELATIONSHIP BETWEEN MOTIVATION OF CHOOSING TEACHING AS A CAREER AND STUDY CHOICE SATISFACTION AMONG SLOVAK TEACHER TRAINEES
}

\author{
[VZTAH MOTIVACIE VYBERU UCITELSKEJ PROFESIE A \\ SPOKOJNOSTI S JEJ VYBEROM U STUDENTOV UCITELSTVA]
}

\author{
Robert Tomsik
}

\author{
doi: 10.18355/PG.2016.5.1.3-13
}

\begin{abstract}
The present research aims to establish which motives are important for choosing the teaching profession and points out the satisfaction with the choice of the profession. Moreover, the present research stresses the importance of motivational factors. A research sample consisted of 159 first grade bachelor degree teacher trainees from Prešov University and University of Constantine the Philosopher in Nitra, Slovak Republic. In order to determine the types of motivation for choosing teaching profession, a SMVUP II scale was used. The satisfaction with the choice of profession was assessed using the one-question indicator of satisfaction. The research results showed that the most important factors of choosing teaching profession are: the interest to work with children and adolescents, the intrinsic value of teaching as well as competence and previous teaching experience. The least frequent motives are labor mobility, salary, and other benefits of teaching profession. Furthermore, the research stressed the differences in the level of satisfaction with the choice of the profession. The research also showed a significant correlation of some of the motivational types (work with children, perception of own competence, prosociality) with the choosing teaching as a profession, which supported the hypothesis about the relationship between specific types of motivation and satisfaction with the choice of teaching profession.
\end{abstract}

\section{Key words}

choice of occupation, teacher, teacher profession, motivation of choosing profession, motivation, SMVUP II

\begin{abstract}
Abstrakt
Tento výskum zist'uje, ktoré motívy sú dôležité pre výber učitel'skej profesie a poukazuje na spokojnost' s vol'bou povolania, rovnako ako aj na význam motivačných faktorov. Do štúdie bolo zahrnutých 159 študentov učitel'stva prvých ročníkov bakalárskeho stupňa Prešovskej univerzity a Univerzity Konštantína Filozofa $v$ Nitre. Typy motivácie vol'by učitel'ského povolania boli zist'ované pomocou SMVUP II Škály vol'by výkonu učitel'ského povolania, kým spokojnost' s výberom tejto profesie bola zist'ovaná pomocou jednopoložkového ukazovatel'a spokojnosti. Výsledky výskumu ukázali, že najdôležitejšími faktormi vol'by učitel'skej
\end{abstract}

Slavonic Pedagogical Studies Journal, ISSN 1339-8660, Volume 5 Issue 1, February 2016 
profesie sú záujem o prácu s det'mi a mladistvými, vnútorná hodnota vyučovania, rovnako ako kompetencie a predošlé skúsenosti s vyučovaním. Najmenej frekventované motívy sú pracovná mobilita, mzda a ostatné benefity učitel'ského povolania. Výskum tiež poukázal na rozdiely v miere spokojnosti s výberom povolania. Niektoré z motivačných typov (práca $\mathrm{s}$ det'mi, vnímanie vlastnej kompetencie, prosocialita), štatisticky významne korelovali so spokojnost'ou s výberom výkonu učitel'skej profesie, čím sme podporili hypotézy o vzt’ahu medzi jednotlivými typmi motivácie a spokojnosti s výberom a výkonom učitel'ského povolania.

\section{Kl'účové slová}

vol'ba povolania, učitel', učitel'ská profesia, motívy vol'by výkonu povolania, motivácia, SMVUP II

\section{Úvod}

Početné empirické zistenia naznačujú, že osobnost' učitel’a vplýva na výsledky vzdelávania žiakov. Dorman, Fisher a Waldrip (2006) poukazujú na to, že kvalita interakcie medzi učitel'om a študentmi determinuje ich učenie, zatial' čo Wang, Heartel a Walberg (1993) dospeli k záveru, že interakcia má takmer rovnaký účinok na učenie, ako aj charakteristiky študentov. Rad autorov naznačuje súvislost' medzi správaním učitel'ov a študijnými výsledkami študentov, či už je toto správanie konkretizované prostredníctvom vyučovacích metód (Carpenter, 2006; De Caprariis, Barman, Magee, 2001; Perkins, Saris, 2001; Yoder, Hochevar, 2005; Vizek-Vidovic, Vlahovic-Stetic, Rijavec, Miljkovicc 2003; Zahed, Moeni, 2010), spôsobom riadenia edukačného procesu (Wang et al, 1993), interpersonálnymi vzt’ahmi (Koul, Fisher, 2006) alebo nejakým iným spôsobom.

Organizácia pre ekonomickú spoluprácu a rozvoj (OECD, 2005) skúmala špecifické otázky edukácie a vzdelávaciu politiku pri získavaní a udržiavaní si efektívnych učitel'ov na pracovisku v dvadsiatich piatich krajinách sveta. Štúdia potvrdila, že vplyvom na kvalitu učitel'ov je možné zlepšit študijné výsledky študentov, t.j. že „kvalita“ učitel'ov je jediným a najdôležitejších faktorov školskej úspešnosti študentov, ale zatial' nie je potvrdené, ktoré kvality učitel'ov sú jej indikátormi. V kontexte tohto problému, v poslednom desat'ročí sa intenzívne skúma motivácia vol’by výkonu povolania učitel'ov. Výskumy poukazujú, že učitelia vykazujú nižšiu úroveň motivácie pre učitel'ské povolanie a vyššiu úroveň stresu v porovnaní s inými profesiami (Kyriacou, 2001; Neves de Jesus, Lens, 2005). Napriek tomu, že učitel'ská profesia je ponímaná ako náročná a stresujúca (Lucic, 2007), a početné štúdie poukazujú na znížené sociálne postavenie učitel'a (Jukic, Reic-Ercegovac, 2008; Lucic, 2007; Radeka, Soric, 2006), výsledky výskumov poukazujú, že študenti učitel'stva sú si vedomí týchto uvedených faktov (Jukic, Reic-Ercegovac, 2008), a teda, nastoluje sa logická otázka: Čo motivuje študentov pre výber učitel'ského povolania napriek týmto skutočnostiam? 


\section{Motivácia vol'by výkonu učitel'ského povolania}

Najčastejšie identifikované motívy vol'by výkonu učitel'ského povolania $\mathrm{v}$ literatúre sú: motívy vnútorné, vonkajšie a altruistické (Brookhart, Freeman, 1992), ktoré sa d’alej členia na špecifickejšie kategórie. Brookhart a Freeman (1992) obzvlášt' zvýraznili vnútorné, vonkajšie a altruistické motívy ako najdôležitejšie skupiny dôvodov, ktoré ovplyvňujú výber kariéry učitel'ov. Identifikované typy motivácie zahŕňali: prácu $\mathrm{s}$ det'mi a dospievajúcimi, sociálnu prospešnost', bezpečnost' práce, výhody práce, radost' $\mathrm{z}$ výučby, kompatibilitu $\mathrm{s}$ inými záujmami a aktivitami, kompatibilitu s rodinným životom a sebavzdelávaním (OECD, 2005). Podl'a výsledkov OECD (2005) štúdie realizovanej vo Francúzsku, Austrálii, Belgicku, Kanade, Holandsku, Slovensku a Vel'kej Británii naznačujú, že túžba pracovat' $\mathrm{s}$ det'mi a mládežou, potenciál pre intelektuálny rast a prostriedky, a možnost' byt' prospešný spoločnosti sú najčastejšie dôvody vol'by výkonu učitel'ského povolania.

$\mathrm{Na}$ druhej strane, štúdie realizované $\mathrm{v}$ iných sociokultúrnych kontextoch (odlišných od Európskej, alebo Americkej), napríklad v Bruneji (Yong, 1995), Zimbabwe (Chivore, 1988), Kamerune (Abangma, 1981) a Jamajke (Bastick, 1999) zistili, že najfrekventovanejšie motívy vol'by učitel'ského povolania sú plat, bezpečnost' práce a sociálny status učitel'a $\mathrm{v}$ spoločnosti (Watt et al., 2012). Táto skutočnost' je však ovplyvnená politickoekonomickou štruktúrou štátu.

P. W. Richardson a H. M. G. Watt (2006) vyvinuli teoretický model výberu učitel'ského povolania na základe teórie očakávania a hodnôt (Eccles, Wigfield, 2002). Tento model predpokladá, že na vol'bu výberu učitel'skej profesie má vplyv vnímanie seba (schopnost' učit'); vnímanie úloh (pracovné požiadavky: odbornost' a zátaž, a výhody práce: stav spoločnosti a plat); hodnoty (osobná utilitárna hodnota: napríklad istota zamestnania, čas pre rodinu, odbornú mobilitu, a sociálna utilitárna hodnota: dopad na budúcnost' detí a dospievajúcich, príspevky na sociálnej rovnosti, prínos pre spoločnost', prácu $\mathrm{s}$ det'mi a dospievajúci); sociálne vplyvy (vplyv ostatných, predchádzajúcich skúsenosti $\mathrm{s}$ výučbou a učením) a „druhá vol'ba“, čiže výber učitel'skej profesie ako rezervnej kariéry.

Podobný model bol vyvinutý aj R. Tomsikom (2015a; 2015b). Konštrukt bol vypracovaný na základe modelu, ktorý predpokladá tri typy motivácie: vnútornú, vonkajšiu a altruistickú. Model indukuje existenciu vplyvu rôznych sociálnych faktorov na osobnost', ktorá je následne rozhodujúcim činitel'om pri vol'be povolania. Model je multifaktorálne podmienený, a za významné možno považovat' vplyv rôznych sociokultúrnych, rodinných, vrstovníckych, osobnostných a iných vplyvov. Poukazuje na odlišné psychologické mechanizmy, ktoré sa podiel'ajú na výbere učitel'stva ako kariéry, ale všetky časti modelu sa podiel'ajú $\mathrm{v}$ procese rozhodovania sa jedinca. Na základe existujúcich výskumov (napríklad Schutz, Crowder, White, 2000; Karikova, 2004; Kasacova, 1996; Musil, 1999 a iní) model indikuje profil ôsmich typov motivácie, ktoré sú začlenené do primárnych kategórií (vnútorná, vonkajšia, altruistická motivácia). Medzi vonkajšie

Slavonic Pedagogical Studies Journal, ISSN 1339-8660, Volume 5 Issue 1, February 2016 
motívy zarad'ujeme napríklad príjem a benefity, ktoré ponúka práca učitel'a; za vnútorné motívy považujeme zanietenost', záujem, kompetencie a pod.; a do poslednej kategórie (altruistické motívy) zarad'ujeme prácu $\mathrm{s}$ mladistvými a prosociálne správanie (Tomsik, 2015a; Tomsik, 2015b).

\section{Vzt'ah motívov a spokojnosti s výberom učitel'ského povolania v empirickom kontexte}

Výsledky výskumov identifikujú existencie súvislosti medzi vnútornou motiváciou pre výkon učitel'ského povolania a kvalitou prístupu k výučbe, ktorá podporuje autonómiu študenta (Pelletier, Séguin-Levésque, Legault, 2002; Reeve, 2006) a vyššiu školskú úspešnost' študentov (Reeve, 2006; Reeve, Bolt, Cai, 1999). L. E. Malmberg (2006) potvrdil, že vnútorná motivácia významne koreluje $\mathrm{s}$ orientáciou jedinca $\mathrm{k}$ učeniu a angažovanosti, zatial' čo vonkajšie typy motivácie orientujú jedinca na vyhýbanie sa úsiliu. I. Marušić, I. Pavin-Ivaneć a V. Vizek-Vidović (2010) zistili, že študenti, ktorí disponujú vyšším sebavedomím a majú lepšiu predstavu o vlastných akademických schopnostiach, sú viac motivovaní $\mathrm{k}$ učeniu, ale aj pre profesiu učitel'a. Autori tiež evidovali výrazne vyššiu vnútornú motiváciu u študentov, ktorým štúdium učitel'stva bolo prvou vol'bou, na rozdiel od študentov, ktorým toto štúdium bolo alternatívnou vol'bou.

Pozitívne posúdenie/hodnotenie osobných zručností pre výkon edukačnej činnosti, sociálne a vnútorné hodnoty vyučovania, a predchádzajúce pozitívne skúsenosti s učením a vyučovaním sú najdôležitejšie dôvody pre výber učitel'stva ako profesie študentov štúdia učitel'stva austrálskych univerzít (Richardson, Watt, 2006; 2007; 2012; Watt, Richardson, Devos, 2013). Uvedené aspekty motivácie študentov prvých ročníkov učitel'stva najvýznamnejšie korelovali s hodnotením spokojnosti s výberom učitel'skej profesie a plánovanej odbornej praxe po skončení štúdia. Spokojnost' s výberom profesie bola spojená aj s odhadmi perspektívneho pôsobenia v profesii, a je dôležitým motivačným faktorom pri rozhodovaní sa o budúcich investíciách pre vlastný profesijný rozvoj a kvalitu výučby (Watt, Richardson, 2007). Vo výskume I. Marusica a kol. (2011), ktorý bol realizovaný na vzorke študentov učitel'stva v Chorvátsku, bolo preukázané, že najsilnejšie motívy sú vôl'a formovat' budúcnost' detí a dospievajúcich, a pracovat' s nimi s ciel'om prispiet' $\mathrm{k}$ spoločnosti, zvýšit' sociálnu rovnost' (altruistické motívy), posúdenie vlastných schopností učit' a vnútorná hodnota výučby (vnútorné motívy). Študenti tiež uvádzali, že považujú povolanie učitel'a za náročné, a vyžaduje si vysokú úroveň odborných znalostí. Inými slovami, pre chorvátskych študentov, podobne ako aj pre austrálskych, sú vel'mi dôležité vnútorné a altruistické motívy, t.j. že je sociálna hodnota silnejšou motiváciou, než sú hodnoty osobné (čas strávený s rodinou, istota zamestnania, finančné ohodnotenie a pod.). Vzt'ah medzi vnútornými s altruistickými motívmi s spokojnost'ou s výberom profesie empirický dokázali aj S. Simic-Sasic, M. Klarin a K. Grbin (2013), M. Fokkens-Bruinsma a E. T. Canrinus (2014), P. W. Richardson a H. M. G. Watt (2006), I. Radeka a I. Soric (2006) a iní. 


\section{Metodológia výskumu \\ Ciele výskumu}

Realizáciou výskumu sme chceli identifikovat', ktoré typy motivácie sú najfrekventovanejšie pri výbere učitel'skej profesie na vzorke vysokoškolských študentov na Slovensku. Druhým ciel'om bolo zistit' úroveň spokojnosti študentov s vol'bou povolania a koreláciu spokojnosti $\mathrm{s}$ výberom povolania s jednotlivými typmi motivácie. Doterajšie empirické zistenia evidujú existenciu vzt’ahu medzi motívmi altruistickými a vnútornými so spokojnost'ou s výberom profesie. Na základe uvedených zistení sme formulovali nasledovné hypotézy:

$\mathbf{H}_{1}$ : Predpokladáme, že existuje štatisticky významný vztah medzi vnútornými motívmi vol'by výkonu učitelského povolania a spokojnostou s výberom učitel'skej profesie.

Koreláciu medzi vnútornými motívmi výberu profesie a spokojnostou $\mathrm{s}$ výberom učitel'skej profesie predpokladáme na základe výskumu SimicSasic, S., Klarin, M. a Grbin, K. z roku 2013, v ktorom autori medzi premennými zistili štatisticky významný vzt’ah $(\mathrm{r}=0.550)$ na hladine 0.01 .

$\mathbf{H}_{2}$ : Predpokladáme, že existuje štatisticky významný vztah medzi altruistickými motívmi vol'by výkonu učitel'ského povolania a spokojnostou $s$ výberom učitel'skej profesie.

Koreláciu medzi altruistickými motívmi výberu profesie a spokojnostou s výberom učitel'skej profesie predpokladáme na základe výskumu FokkensBruinsma, M. a Canrinus. E. T. z roku 2014, v ktorom autori medzi premennými zistili štatisticky významný vzt’ah $(\mathrm{r}=0.370)$ na hladine 0.01 .

\section{Výskumná vzorka}

Výskumnú vzorku tvorili vysokoškolskí študenti Univerzity Konštantína Filozofa v Nitre $(\mathrm{N}=120)$, a študenti Prešovskej univerzity v Prešove $(\mathrm{N}=39)$. Do výskumu bolo zaradených 159 študentov prvých ročníkov bakalárskeho štúdia, kumulovaných do nasledovných skupín (skupiny študijných programov): Učitel'stvo akademických predmetov ( $\mathrm{N}=140)$, Učitel'stvo pre primárne a predprimárne vzdelávanie $(\mathrm{N}=29)$. Vol'ba prvých ročníkov vychádza z predpokladu, že u študentov prvých ročníkov prevláda primárna motivácia vol'by učitel'ského povolania. U študentov vyšších ročníkov primárna motivácia môže byt' $\mathrm{v}$ priebehu štúdia pozmenená vplyvom iných faktorov. Z celkového počtu bolo 40 respondentov mužského pohlavia a 115 respondentiek ženského pohlavia (4 nekategorizovaní). Zber dát prebiehal od 27.10.2015 do 15.01.2016.

\section{Metódy}

Škála motivácie vol'by učitel'ského povolania (SMVUP I-II) vznikla ako inšpirácia na základe často $\mathrm{v}$ zahraničí používanej FIT-Choice škály, ktorej autormi sú Helen M. G. Watt a Paul W. Richardson. Typy motivácie vol'by výkonu povolania učitel’a $\mathrm{v}$ škále vyplývajú $\mathrm{z}$ empirických zistení slovenských a zahraničných autorov. Z doterajších výskumov v oblasti motivácie vol'by výkonu povolania učitel'a indikujeme existenciu 8 typov 
motivácie vol'by učitel'ského povolania: kompetentnost', zanietenie, rodina a benefity, príjem, sociálny status, uznanie, prosociálnost' a práca s det'mi a mladistvými. Každá zo subškál je tvorená tromi až štyrmi položkami. Skóre odpovedí respondentov sa môže pohybovat' v rozmedzí od 3 bodov, ako minimálne skóre do 20 bodov ako maximálne dosiahnutel'né skóre. Vyššie skóre predstavuje vyššiu úroveň faktoru motivácie, na ktorý je škála zameraná. Škála motivácie vol'by učitel'ského povolania obsahuje 30 položiek, na ktoré sa odpovedá pomocou pät'stupňovej stupnice Likertovho typu (1-5). Pôvodná verzia SMVUP (2014) obsahovala 51 položiek, ktoré boli triedené do 9 subškál. Druhá reedícia SMVUP dotazníka (SMVUP I) publikovaná v roku 2015 obsahovala 37 položiek, ktoré boli redukované na základe faktorovej analýzy na 30 (SMVUP II). Cronbachova Alfa celej škály vynáša 0.832 . Pôvodnú, ako aj revidované škály motivácie vol’by učitel'ského povolania autorsky zostavil aj overil R. Tomsik (Tomsik, R. 2015a; 2015b).

Spokojnost' s výberom štúdia učitel'stva bola meraná jednopoložkovým ukazovatel'om spokojnosti na škále Likertovho typu pozostávajúci z pät' stupňov. Vyššie číslo na škále predstavuje vyššiu mieru spokojnosti.

\section{Štatistické spracovanie}

$\mathrm{Na}$ zistenie korelácií medzi jednotlivými položkami a reliability výskumného nástroja sme použili metódy štatistického programu SPSS (Statistical Package For Social Science ver. 20) pre Microsoft Windows. Na základe výsledkov Kolmogorov-Smirnovej $Z$ distribúcie, dáta spíňajú kritérium normality a na zistenie miery korelácie medzi premennými volíme parametrický test Pearsonov koeficient korelácie.

\section{Výsledky}

V tabul'ke č. 1 sú prezentované popisné údaje o intenzite jednotlivých motivačných faktorov, či typov motivácie vol'by povolania, ako aj spokojnosti s výberom uvedeného povolania. Pozorujúc len hodnoty aritmetických priemerov pre každú premennú je zrejmé, že najsilnejšie faktory vol'by výkonu učitel'ského povolania v celej vzorke študentov sú: Zanietenost', Kompetencie, Uznanie, Prosociálnost' a Práca s det'mi a dospievajúcimi. V modeli prevládajú dva faktory spadajúce pod vnútorné motívy (zanietenost' a kompetencie), jeden vonkajší faktor (uznanie), a dva faktory altruistické (prosociálnost' a práca $\mathrm{s}$ det'mi $\mathrm{s}$ dospievajúcimi). Spokojnost' s výberom povolania na našej vzorke študentov sa pohybuje nad aritmetickým priemerom (3.61).

Tabul'ka 1 Deskriptívna štatistika pre celú vzorku v jednotlivých výskumných faktoroch

\begin{tabular}{|c|c|c|c|c|}
\hline Faktor & N & M & SD & SEM \\
\hline Spokojnost' & 150 & 3.607 & 0.889 & 0.072 \\
\hline Zanietenost' & 159 & 13.019 & 3.683 & 0.292 \\
\hline Kompetencie & 159 & 14.346 & 2.627 & 0.208 \\
\hline Sociálny status & 159 & 11.019 & 2.946 & 0.233 \\
\hline Uznanie & 159 & 15.704 & 2.550 & 0.202 \\
\hline
\end{tabular}




\begin{tabular}{|c|c|c|c|c|}
\hline Benefity & 159 & 12.365 & 2.764 & 0.219 \\
\hline Príjem & 159 & 11.036 & 2.511 & 0.199 \\
\hline Prosociálnost' & 159 & 13.698 & 2.467 & 0.195 \\
\hline $\begin{array}{c}\text { Práca s det'mi } \\
\text { a dospievajúcimi }\end{array}$ & 159 & 14.448 & 4.395 & 0.348 \\
\hline
\end{tabular}

N- počet; M- priemer; SD- štandardná deviácia; SEM- štandardná chyba priemeru.

\section{Hypotéza č. 1 a č. 2}

$\mathbf{H}_{1}$ : Predpokladáme, že existuje štatisticky významný vzt’ah medzi vnútornými motívmi vol'by výkonu učitel'ského povolania a spokojnostou s výberom učitel'skej profesie.

$\mathbf{H}_{2}$ : Predpokladáme, že existuje štatisticky významný vztiah medzi altruistickými motívmi vol'by výkonu učitel'ského povolania a spokojnostou $s$ výberom učitel'skej profesie.

Štatistickou analýzou pomocou Pearsonovho koeficientu korelácie sme zistili štatisticky významný vzt’ah medzi vnútornými motívmi Kompetencie a Zanietenost' a spokojnost'ou s výberom učitel'skej profesie na hladine štatistickej významnosti 0.01 (Tabul'ka 2). Signifikantnú mieru korelácie na hladine 0.01 zaznamenávame aj medzi jednotlivými motivačnými faktormi: Zanietenost' a Kompetencie $(\mathrm{r}=495)$, Kompetencie a Práca $s$ det’mi a dospievajúcimi ( $\mathrm{r}=428)$, a Uznanie a Prosociálnost' $(\mathrm{r}=492)$.

\section{Tabul'ka 2 Výsledky korelačnej analýzy}

\begin{tabular}{|cc|c|c|c|c|c|c|c|c|}
\hline \multicolumn{2}{c}{$\mathrm{S}$} & $\mathrm{A}$ & $\mathrm{B}$ & $\mathrm{C}$ & $\mathrm{D}$ & $\mathrm{E}$ & $\mathrm{F}$ & $\mathrm{G}$ & $\mathrm{H}$ \\
$\mathrm{S}$ & 1 & $0.316^{* *}$ & $0.450^{* *}$ & $0.205^{*}$ & 0.095 & 0.093 & 0.125 & $0.164^{*}$ & $0.233^{* *}$ \\
\hline $\mathrm{A}$ & $0.316^{* *}$ & 1 & $0.495^{* *}$ & $0.379^{* *}$ & 0.097 & -0.021 & $0.286^{* *}$ & 0.150 & $0.177^{*}$ \\
\hline $\mathrm{B}$ & $0.450^{* *}$ & $0.495^{* *}$ & 1 & $0.303^{* *}$ & $0.249^{* *}$ & 0.119 & $0.194^{*}$ & $0.205^{* *}$ & $0.428^{* *}$ \\
$\mathrm{C}$ & $0.205^{*}$ & $0.379^{* *}$ & $0.303^{* *}$ & 1 & $0.156^{*}$ & 0.009 & $0.370^{* *}$ & $0.166^{*}$ & 0.100 \\
\hline $\mathrm{D}$ & 0.095 & 0.097 & $0.249^{* *}$ & $0.156^{*}$ & 1 & 0.028 & -0.045 & $0.492^{* *}$ & $0.262^{* *}$ \\
$\mathrm{E}$ & 0.093 & -0.021 & 0.119 & 0.009 & 0.028 & 1 & $0.258^{* *}$ & 0.005 & 0.019 \\
\hline $\mathrm{F}$ & 0.125 & $0.286^{* *}$ & $0.194^{*}$ & $0.370^{* *}$ & -0.045 & $0.258^{* *}$ & 1 & 0.076 & 0.068 \\
$\mathrm{G}$ & $0.164^{*}$ & 0.150 & $0.205^{* *}$ & $0.166^{*}$ & $0.492^{* *}$ & 0.005 & 0.076 & 1 & $0.251^{* *}$ \\
$\mathrm{H}$ & $0.233^{* *}$ & $0.177^{*}$ & $0.428^{* *}$ & 0.100 & $0.262^{* *}$ & 0.019 & 0.068 & $0.251^{* *}$ & 1 \\
\hline
\end{tabular}

**. Korelácia je významná na hladine štatistickej významnosti 0.01 .

*. Korelácia je významná na hladine štatistickej významnosti 0.05 .

S- Spokojnost; A- Zanietenost; B- Kompetencie; C- Sociálny status; D- Uznanie; E-Benefity; F-Príjem; G- Prosociálnost'; H- Práca s det'mi a dospievajúcimi.

\section{Diskusia a závery}

Pozorujúc len aritmetické priemery, faktor s najvyšším priemerom je Uznanie. Predpokladáme, že študenti sa domnievajú, že povolanie vyžaduje vel’a znalostí a zručností, a že ich budúca práca bude náročná a t’ažká. Študent si reflektuje uvedomenie si náročnosti práce učitela a ponímaný prestíž učitel'ského povolania v spoločnosti. Ďalej sú to faktory vnútorných hodnôt - kompetencie a zanietenost'. Pod kompetenciami chápeme skôr

Slavonic Pedagogical Studies Journal, ISSN 1339-866o, Volume 5 Issue 1, February 2016 
skúsenosti s vyučovaním, než vedomosti viazané na pedagogiku. Študenti ponímajú, že ich kompetencie sú vhodné na výkon učitel'skej profesie (veria, že toto povolanie vyhovuje ich schopnostiam), ale tak isto aj miera odhodlanosti, alebo záujem venovat' sa učitel'skému povolaniu - vnútorná zál'uba k obsahu profesie je vysoko hodnotená. Ako dôležité sa javia aj faktory altruistické - práca s mládežou a faktor prosociality. Študenti si volili učitel'skú profesiu, pretože chcú pracovat's det'mi, umožní im ovplyvňovat' deti a mladých l'udí. Študenti sa tiež domnievajú, že s povolaním učitel'a môžu významne prispiet' k spoločnosti. Najmenej frekventované faktory pri výbere výkonu práce učitel'ov pre študentov sú Benefity (vol'ný čas a profesijná mobilita), Príjem (mzda, finančné ohodnotenie) a Sociálny status (postavenie v spoločnosti). Kým spoločnost' sa domnieva, že učitelia majú ,dlhé“ prázdniny a kratšiu pracovnú dobu, zdá sa, že študentom tento faktor nehrá vel'kú úlohu pri vol'be povolania. Taktiež postavenie učitel'a v spoločnosti a jeho finančné ohodnotenie sú tiež dôvody, ktoré odpudzujú študentov od vol'by výkonu učitel'ského povolania (Tabul'ka 1).

Úroveň spokojnosti s výberom profesie považujeme za uspokojivú $(\mathrm{M}=3.61)$. Výsledky štúdie ukázali, že v spojitosti so spokojnost'ou s výberom profesie, najdôležitejšiu úlohu majú predovšetkým motívy vnútorné a altruistické. Ukázalo sa tiež, že dôležitú funkciu pri spokojnosti s vol'bou profesie má motív jej vol'by. Motivačné faktory ako sú záujem o prácu sdet'mi a mladistvými, vnútorná hodnota vyučovania a najmä kompetencie študenta, čiže vnímanie ich schopnosti vyučovat' sú vel'mi dôležitými prediktormi vol'by profesie ale aj spokojnosti s týmto výberom. Ako tvrdí H. Watt (2007), motivačný faktor pri vol'be profesie sa odrazí na budúcich investíciách, angažovanosti a vlastnom profesijnom rozvoji a kvality výučby. Vnútorná motivácia vol'by povolania učitel'a výučby súvisí $\mathrm{s}$ kvalitnejším prístupom $\mathrm{k}$ vyučovaniu, ktorý podporuje samostatnost' študenta (Pelletier et al., 2002; Reeve, 2006), vnútornou motiváciou a vyššou školskou úspešnost'ou študentov. Zdá sa, že ona a spokojnost' s výberom povolania môžu byt' skutočne dobrým ukazovatel'om "kvality" budúcich učitel'ov.

Tieto výsledky korešpondujú so zisteniami iných autorov na vzorkách študentov učitel'stva akademických predmetov, či učitel'stva primárneho a predprimárneho vzdelávania v Chorvátsku, ale aj s výsledkami získaných na vzorke amerických, britských a austrálskych študentov (Richardson, Watt, 2006; Marusic et al., 2011). Rozdiely, ktoré zaznamenávame vzhl'adom na zahraničné zistenia, sú v miere faktoru Uznanie, ktorý je vo výsledkoch zahraničných výskumov uvádzaný ako jeden z najmenej imponujúcich. Z výskumu vyplýva, že ako problematické kategórie sa javia: sociálny status - sociálny status učitel'ského povolania odradí vel'ký počet nádejných učitel'ov, pokles sociálneho statusu učitel'ov na Slovensku je podmienený multifaktorálne; benefity, ktoré ponúka práca učitel'a, alebo samotná charakteristika učitel'skej profesie. Študentov často odrádza skutočnost', že učitelia majú ,,prácu doma aj po práci v školskom zariadení“, znižujú sa práva učitel'a a stúpajú povinnosti a zodpovednost'; a príjem - 
problematika nízkeho ohodnotenia práce učitel'ov je rokmi aktuálnou témou, študenti často volia lukratívnejšie profesie (Tomsik, 2015a).

\section{Bibliographic references}

ABANGMA, M. A. 1981. A study of primary teachers' attitudes towards rualisation of school curriculum in English speaking Cameroon. Unpublished Ph.D tehsis. London : University of London.

BASTICK, T. 2000. Why teacher trainees choose the teaching profession? Comparing trainees in metropolitan and developing countries. In International Review of Education, vol. 46, no. 3/4, pp. 343-349.

BROOKHART, S. M. - FREEMAN, D. J. 1992. Characteristics of entering teacher candidates. In Review of Educational Research, vol. 62, no. 1, pp. 37-60.

CARPENTER, J. M. 2006. Effective teaching methods for large classes. In Journal of Family and Consumer Sciences Education, vol. 24, no. 2, pp. 1323.

DE CAPRARIIS, P. - BARMAN, C. - MAGEE, P. 2001. Monitoring the benefits of active learning exercises in introductory survey courses in science: An attempt to improve the education of prospective public school teachers. In The Journal of Scholarship of Teaching and Learning, vol. 1, no. 2, pp. 1-11.

DORMAN, J. P. - FISHER, D. L. - WALDRIP, B. G. 2006. Classroom environment, students' perceptions of assessment, academic efficacy and attitude to science: A Lisrel analysis. In D. L. Fisher, M. S. Khine. In Contemporary Approaches to Research on Learning Environments Worldviews. Singapore : World Scientific.

ECCLES, J. S. - WIGFIELD, A. 2002. Motivational beliefs, values, and goals. In: Annual Review of Psychology, vol. 53, pp. 109-132.

FOKKENS-BRUINSMA, M. - CANRINUS, E. T. 2014. Motivation for becoming a teacher and engagement with the profession: Evidence from different contexts. In International Journal of Educational Research, vol. 65, pp. 65-74.

CHIVORE, B. S. R. 1988. A reviewof factors that determine the attractiveness of teaching profession in Zimbabwe. In International Review of Education, vol. 34, no. 1, pp. 59-77.

JUKIC, T. - REIC-ERCEGOVAC, I. 2008. Zanimanja ucitelja i odgajatelja iz perspektive studenata. In Metodički obzori, vol. 3, no. 2, pp. 73-82.

KARIKOVA, S. 2004. Špecifiká profesijnej dráhy učiteliek. MPC : Prešov. 60 s. ISBN 80-8045-335-7.

KASACOVA, B. 1996. Ocakavania a predstavy studentov ucitelstva 1. stupňa Z $\breve{S}$ a ich postoje $\mathrm{k}$ pedagogicko-psychologickej príprave. In Pedagogická revue, roč. 48, č. 7-8, s. 311-317.

KOUL, R. B. - FISHER, D. L. 2006. Students' perceptions of teachers' interpersonal behaviour and identifying exemplary teachers. [cit. 2015-311]. Available online: http://ctl.curtin.edu.au/events/ conferences/ tlf/tlf2006/refereed/koul.html 
KYRIACOU, C. 2001. Teacher Stress: Directions for future research. In: Educational Review, vol. 53, no. 1, pp. 27-35.

LUCIC, K. 2007. Odgojiteljska profesija u suvremenoj odgojno-obrazovnoj ustanovi. In Odgojne znanosti, vol. 9, no. 1, pp. 151-164.

MALMBERG, L. E. 2006. Goal orientation and teacher motivation among teacher applicants and student teachers. In Teaching and Teacher Education, vol. 22, pp. 58-76.

MARUŠIĆ, I. - JUGOVIC, I. - PAVIN IVANEC, T. 2011. Primjena teorije vrijednosti i očekivanja u kontekstu odabira učiteljske profesije. In Psihologijske teme, vol. 20, no. 2, pp. 299-318.

MARUSIC, I. - PAVIN IVANEC, I. - VIZEK VIDOVIC, V. 2010. Neki prediktori motivacije za učenje u budućih učitelja i učiteljica. Psihologijske teme, vol. 19, no. 1, pp. 31-44.

MUSIL, J. V. et al. 1999. Zdroje a prostriedky pedagogiky prof. ThDr. Františka kardinála Tomáška. Olomouc: MCM. ISBN 80-7266-031-4.

NEVES DE JESUS, S. - LENS, W. 2005. An integrated model for the study of teacher motivation. In Applied Psychology : An International Review, vol. 54, no .1, pp. 119-134.

OECD. 2005. Teachers matter: Attracting, developing and retaining effective teachers. OECD Publishing.

PELlETIER, L. - SÉGUIN-LÉVESQUE, C. - LEGAULT, L. 2002. Pressure from above and pressure from below as determinants of teachers' motivation and teaching behaviors. In Journal of Educational Psychology, vol. 94, no. 1, pp. 186-196.

PERKINS, D. - SARIS, N. 2001. A jigsaw classroom technique for undergraduate statistics courses. In Teaching of Psychology, vol. 28, no. 2, pp. 111-113.

RADEKA, I. - SORIC, I. 2006. Zadovoljstvo poslom i profesionalni status nastavnika. In Napredak, vol. 147, no. 2, pp. 161-177.

REEVE, J. 2006. Teachers as facilitators: What autonomy-supportive teachers do and why their students benefit. In The Elementary School Journal, vol. 106, no. 3, pp. 225-237.

REEVE, J. - BOLT, E. - CAI, Y. 1999. Autonomy-supportive teachers: How they teach and motivate students. In Journal of Educational Psychology, vol. 91, pp. 537-548.

RICHARDSON, P. W. - WATT, H.M.G. 2006. Who chooses teaching and why? Profiling characteristics and motivations across three Australian universities. In Asia-Pacific Journal of Teacher Education, vol. 34, no. 1, pp. 27-56.

SCHUTZ, P. A. - CROWDER, K. C. - WHITE, V. E. 2001. The Development of a Goal to Becomea Theacher. In Journal of Educational Psychology, vol. 93, no. 2, pp. 299-309.

SIMIC-SASIC, S. - KLARIN, M. - GRBIN, K. 2013. Motivacija za učiteljski poziv, zadovoljstvo studijem i zadovoljstvo izborom zanimanja. In Magistra Iadertina, vol. 8, no. 1, pp. 7-26.

TOMSIK, R. 2015a. Gender Differences In Motivations For Choosing Teaching As A Career. In Evropske pedagogicke forum 2015: prinosy, 
vyzvy, ocekavani. Sbornik z mezinarodni vedecke konference. Hradec Kralove: Magnanimitas, pp. 130-137. ISBN 978-80-87952-11-5.

TOMSIK, R. 2015b. Skala motivacie volby ucitelskeho povolania. MMK. In Sbornik prispevku z mezinarodni vedecke konference. Hradec Kralove: Magnanimitas, pp. 1213-1221. ISBN 978-80-87952-12-2.

VIZEK-VIDOVIC, V. - VLAHOVIC-STETIC, V. - RIJAVEC, M., MILJKOVIC, D. 2003. Psihologija obrazovanja. Zagreb: IEP-VERN.

WANG, M. C. - HEARTEL, G. D. - WALBERG, H. J. 1993. Toward a knowledge base for school learning. In Review of Educational Research, vol. 63, no. 3, pp. 249-294.

WATT, H. M. G. - RICHARDSON, P. W. 2007. Motivational factors influencing teaching as a career choice: Development and validation of the FIT-Choice scale. In The Journal of Experimental Education, vol. 75, pp. 167-202.

WATT, H. M. G. - RICHARDSON , P. W. - DEVOS, C. 2013. Initial teaching motivations, professional engagement, and subsequent teaching behavior. In Teacher motivations in international context, vol. 5, pp. 27-31.

WATT, H. M. G. - RICHARDSON. P. W. 2012. An introduction to teaching motivations in different countries: comparisons using the FITChoice scale. In Asia-Pacific Journal of Teacher Education, vol. 40, pp. 185-197. ISSN 1359-866X.

WATT, H. M. G. - RICHARDSON. P. W. 2006. Who chooses teaching and why? Profiling characteristics and motivations across three Australian universities. In Asia-Pacific Journal of Teacher Education, vol. 4, pp. 27-56. ISSN 1359-866X.

YODER, J. - HOCHEVAR, C. 2005. Encouraging active learning can improve students' performance on examinations. In Teaching of Psychology, vol. 32, no. 2, pp. 91-95.

YONG, B. C. S. 1995. Teacher trainees' motives for entering into a teaching career in Brunei Darussalam. In Teaching and Teacher Education, vol. 11 , no. 3, pp. 275-280.

ZAHED, A. B. - MOENI, M. K. 2010. Study of teacher-students interaction in teaching process and its relation with students' achievement in primary schools. In The Social Sciences, vol. 5, no. 1, pp. 55-59.

Mgr. Robert Tomšik

Department of Education

Faculty of Education

Constanine the Philosopher University

Dražovská cesta 4, 94974 Nitra

Slovakia

robert.tomsik@ukf.sk 